Bangladesh J. Pl. Breed. Genet., 26(1): 25-33, 2013

\title{
GENETIC VARIABILITY, CORRELATION AND PATH COEFFICIENT ANALYSIS OF YIELD AND QUALITY TRAITS IN PUMPKIN (Cucurbita moschata Duch ex Poir.)
}

\author{
S. Akter, M. G. Rasul, A. K. M. Aminul Islam and M. M. Hossain ${ }^{1}$ \\ Department of Genetics and Plant Breeding \\ Bangabandhu Sheikh Mujibur Rahman Agricultural University \\ Gazipur 1706, Bangladesh.
}

\begin{abstract}
The experiment was conducted to study variability, correlation coefficient and path analysis for yield and quality related traits of 30 pumpkin genotypes. Significant variations were found among the genotypes for most of the characters studied. High genotypic coefficient of variation (GCV) and high heritability coupled with high genetic advance in percent of mean were observed for beta-carotene followed by non-reducing sugar, number of seeds per fruit, yield per plant, dry weight, flesh thickness, number of male flowers per plant and number of female flowers per plant which indicated that these characters were under additive gene control and selection for genetic improvement for these traits might be effective. Correlation co-efficient between yield per plant with number of primary branches, number of fruits per plant and single fruit weight were positive and highly significant. On the other hand, days to first female flower, number of male flowers per plant, $\beta$ - carotene and total sugar showed positive and insignificant correlation with yield per plant. But correlation between brix content and yield per plant were significantly negative. Path coefficient analysis revealed that the maximum direct contribution towards yield was obtained through number of fruits per plant followed by days to first female flower and single fruit weight indicated that these traits should be considered as primary components of yield. Negative direct effect on yield was exerted by total sugar followed by number of female flowers per plant, reducing sugar and brix content. Considering all the qualitative and quantitative traits ten genotypes as $G_{7}, G_{13}, G_{14}, G_{17}, G_{18}, G_{19}, G_{20}, G_{22}, G_{27}, G_{29}$ among thirty were selected and suggested to be selfed for the development of inbred line for use in future breeding programme.
\end{abstract}

Key words: Variability, Heritability, Genetic advance, Correlation, Path co-efficient and Pumpkin.

\section{INTRODUCTION}

Pumpkin (Cucurbita moschata) is locally known as 'Misti kumra' or 'Misti lau' or 'Misti kadu'. It belongs to the family Cucurbitaceae having chromosome number $2 \mathrm{n}=$ 40. There are 27 species under the genus Cucurbita, five of which are in cultivation. These are C. moschata, C. maxima, C. ficifolia, C. pepo and C. mixta, commonly known as Pumpkin. C. moschata is probably the most widely grown species of Cucurbita and

\footnotetext{
${ }^{1}$ Dept. of Horticulture, Bangabandhu Sheikh Mujibur Rahman Agricultural University, Gazipur 1706, Bangladesh.
} 
this species is cross compatible with C. maxima, C. pepo and C. mixta (Tindall, 1987). Pumpkin is relatively high in energy and carbohydrates and a good source of vitamins, especially high carotenoid pigments and minerals (Bose and Som, 1998). The nutrient per $100 \mathrm{~g}$ edible portions of fruit is $90 \mathrm{ml}$ water, $8 \mathrm{~g}$ carbohydrate, $1 \mathrm{~g}$ protein, $0.5 \mathrm{~g}$ fibers, $20 \mathrm{mg}$ calcium, $0.8 \mathrm{mg}$ iron, $210 \mathrm{mg}$ beta-carotene, $0.05 \mathrm{mg}$ thiamine, $0.05 \mathrm{mg}$ riboflavin, $0.5 \mathrm{mg}$ niacin and $15 \mathrm{mg}$ ascorbic acid (Tindall, 1987). It may contribute to improve the nutritional status of the people, particularly the vulnerable groups in respect of vitamin A requirement. In Bangladesh, the area under cultivation of pumpkin is 9,600ha with a total production of 38,500t/ annum) (BBS, 2009).

Though a fairly common crop, to-date there is no released variety of pumpkin with high yield potential and good quality in Bangladesh (Jahan et al., 2012). Lack of high yielding, disease and pest tolerant variety is the main constrains towards its production. Furthermore, very limited attempt has been made for genetic improvement of this crop. As pumpkin is highly cross pollinated crop so a good knowledge of genetic resources might also help in identifying desirable cultivars for commercial cultivation. For this, inbreed line should be developed through selfing and selection in local and exotic germplasms. There are number of local cultivars with wide range of variability in size, shape and color of fruits available in Bangladesh that can be exploited for its improvement and by this we can easily fulfill the gap by developing high yielding hybrid variety. Besides, information on quality aspects of fruits is very scanty in Bangladesh. So it is the demand to a breeder to develop high yielding with high quality varieties through selection, either from the existing genotypes or from the segregates of a cross. Information on variability, character association and path coefficient analysis in respect of yield, its contributing characters and quality aspects required to be properly assessed for its improvement. Therefore, the present study was undertaken to estimate the genetic variation, the correlation coefficients and path-coefficient and to screen out the suitable parental groups with better performances for future breeding program in the thirty genotypes of pumpkin.

\section{MATERIALS AND METHODS}

The experiment was conducted with 30 accessions of pumpkin at the Research Farm of the Bangabandhu Sheikh Mujibur Rahman Agricultural University (BSMRAU) Salna, Gazipur during the growing season 2011-12. Thirty pumpkin genotypes maintained by the Department of Genetics and Plant Breeding, BSMRAU were used as experimental materials (Table 1). The experiment was laid out in a Randomized Complete Block Design (RCBD) with three replications. The distance between plot and block were $100 \mathrm{~cm}$. The seeds were sown in $(9 \times 18) \mathrm{cm}^{2}$ diameter polyethylene bags on $3^{\text {rd }}$ November 2011. Three seeds were sown in each bag. The germination medium was prepared by mixing compost and soil in 50:50 proportions. Intensive care was taken for production of healthy seedlings. The plots were raised $10 \mathrm{~cm}$ above ground level. Pits of $50 \times 50 \times 30 \mathrm{~cm}^{3}$ size were dug at a spacing of $2 \times 2 \mathrm{~m}^{2}$. Each pit was fertilized with $10 \mathrm{~kg}$ Cow dung, 52g TSP, 60g Urea and 40g MP respectively to ensure proper growth and development of plant (Brammer, 1971). Cowdung and pit soil were mixed together. One-third of urea and the entire quantity of other fertilizers were applied at final land preparation. The rest two-thirds of urea were top dressed before the time of branching and flowering in two installments. Twenty days old seedlings were transplanted in wellprepared experimental plot on $22^{\text {nd }}$ November 2011. The seedlings were watered immediately after transplanting. Four plants of each genotype were accommodated in each replicated plot maintaining $2 \times 2 \mathrm{~m}^{2}$ spacing. Routine weeding was done to keep the 
field free from weeds and to pulverize the soil. Irrigation was done as and when required. The fruits were harvested when the peduncle dried on maturity. Data were recorded for Days to first male flower, Days to first female flower, Number of male flowers per plant, Number of female flowers per plant, Number of primary branches per plant, Number of secondary branches per plant, Fruit Diameter $(\mathrm{cm})$, Fruit length $(\mathrm{cm})$ Flesh thickness $(\mathrm{cm})$, Hollowness $(\mathrm{cm})$, Number of fruits per plant, Single fruit weight $(\mathrm{kg})$, Number of seeds per fruit, Dry matter content, Total soluble solid, Beta-carotene $(\mathrm{mg} / 100 \mathrm{~g})$, Total sugar $(\mathrm{g} / 100 \mathrm{~g})$, Reducing sugar $(\mathrm{g} / 100 \mathrm{~g})$, Non-reducing sugar $(\mathrm{g} / 100 \mathrm{~g})$ and Yield per plant $(\mathrm{kg})$. The data were analyzed to estimate genotypic and phenotypic co-efficient of variation using the formula of Burton (1952), heritability in broad sense using the formula of Lush (1949), genetic advance and correlation co-efficient were estimated by the following formula, suggested by Johnson et al. (1955). Path analysis was worked out as suggested by Dewey and Lu (1959). Mean, range and co-efficient of variation (CV \%) were estimated using MSTAT-C.

Table1. List of thirty pumpkin genotypes used as experimental materials

\begin{tabular}{|c|c|c|c|c|c|}
\hline SI. No. & Genotype No. & Pedigree & SI. No. & Genotype No. & Pedigree \\
\hline 01 & $\mathrm{G}_{1}$ & $\mathrm{OP}_{23} \mathrm{OPS}_{1}$ & 16 & $\mathrm{G}_{16}$ & $\mathrm{OP}_{40} \mathrm{~S}_{1}$ \\
\hline 02 & $\mathrm{G}_{2}$ & $\mathrm{OP}_{50} \mathrm{OPS}_{2}$ & 17 & $\mathrm{G}_{17}$ & $\mathrm{OP}_{51} \mathrm{BOP}$ \\
\hline 03 & $\mathrm{G}_{3}$ & $\mathrm{~F}_{2} \mathrm{Max} \times \mathrm{XP}_{23} \mathrm{~S}_{2}$ & 18 & $\mathrm{G}_{18}$ & $\mathrm{OP}_{32} \mathrm{OPxOP}_{40} \mathrm{OP}$ \\
\hline 04 & $\mathrm{G}_{4}$ & $\mathrm{OPS}_{1} \mathrm{BS}_{0}$ & 19 & $\mathrm{G}_{19}$ & $\mathrm{OP}_{23} \mathrm{~S}_{0}$ \\
\hline 05 & $\mathrm{G}_{5}$ & Suprema $\left(F_{4}\right)$ & 20 & $\mathrm{G}_{20}$ & $\mathrm{OP}_{57}$ round $_{0} \mathrm{xOP} \mathrm{OP}_{47} \mathrm{~S}_{0}$ \\
\hline 06 & $\mathrm{G}_{6}$ & 3Lobbed $\mathrm{S}_{3}$ & 21 & $\mathrm{G}_{21}$ & $\mathrm{OP}_{57} \mathrm{BOP}$ self \\
\hline 07 & $\mathrm{G}_{7}$ & $\mathrm{OP}_{23} \mathrm{~S}_{2}$ & 22 & $\mathrm{G}_{22}$ & $\operatorname{Max} \times \mathrm{OP}_{23} \mathrm{~S}_{0}$ \\
\hline 08 & $\mathrm{G}_{8}$ & $\mathrm{OP}_{50} \mathrm{~S}_{3}$ & 23 & $\mathrm{G}_{23}$ & $\mathrm{OP}_{51}$ Bself OP \\
\hline 09 & $\mathrm{G}_{9}$ & $\mathrm{OP}_{47} \mathrm{~S}_{3}$ & 24 & $\mathrm{G}_{24}$ & $\mathrm{OP}_{47} \mathrm{~S}_{1}$ \\
\hline 10 & $\mathrm{G}_{10}$ & $\mathrm{OP}_{57} \mathrm{~S}_{3}$ & 25 & $\mathrm{G}_{25}$ & $\mathrm{OP}_{50} \mathrm{~S}_{1}$ \\
\hline 11 & $\mathrm{G}_{11}$ & $\mathrm{OP}_{35} \mathrm{~S}_{2}$ & 26 & $\mathrm{G}_{26}$ & $\mathrm{OP}_{57} \mathrm{BS}_{1}$ \\
\hline 12 & $\mathrm{G}_{12}$ & $\mathrm{OP}_{40} \mathrm{~S}_{2}$ & 27 & $\mathrm{G}_{27}$ & $\mathrm{OP}_{35}$ self \\
\hline 13 & $\mathrm{G}_{13}$ & $\mathrm{OP}_{57} \mathrm{BOS}_{2}$ & 28 & $\mathrm{G}_{28}$ & $\mathrm{OP}_{36} \mathrm{OP}$ \\
\hline 14 & $\mathrm{G}_{14}$ & Sweety & 29 & $\mathrm{G}_{29}$ & $\mathrm{OP}_{23}$ self $\mathrm{OPS}_{0}$ \\
\hline 15 & $\mathrm{G}_{15}$ & Dreamgold & 30 & $\mathrm{G}_{30}$ & $\mathrm{OP}_{32} \mathrm{~S}_{0}$ \\
\hline
\end{tabular}

\section{RESULTS AND DISCUSSION}

Mean square obtained from analysis of variance (ANOVA) for yield and quality traits are presented in Table 2. It revealed from mean square values that there were significant differences among the accessions for all the characters.

Table 2. Analysis of variance for twenty yield and quality related traits in pumpkin

\begin{tabular}{l|c|l|l|l|l|l}
\hline $\begin{array}{c}\text { Sources of } \\
\text { variation }\end{array}$ & df & \multicolumn{1}{c|}{ DFMF } & \multicolumn{1}{c|}{ DFFF } & \multicolumn{1}{c}{ NMFP } & \multicolumn{1}{c}{ NFFP } & \multicolumn{1}{c}{ NPBP } \\
\hline Replication & 2 & 4.40 & 13.60 & 30.005 & 5.21 & 10.8 \\
Treatment & 29 & $86.63^{* *}$ & $23.58^{* *}$ & $456.68^{* *}$ & $16.32^{* *}$ & $2.59^{* *}$ \\
Error & 58 & 1.32 & 1.85 & 0.005 & 0.83 & 0.83 \\
\hline
\end{tabular}

Table 2 continued

\begin{tabular}{l|l|l|l|l|c|c|c}
\hline \multicolumn{1}{c}{ NSBP } & \multicolumn{1}{c}{ FD } & \multicolumn{1}{c}{ FL } & \multicolumn{1}{c|}{ FT } & HW & NFP & SFW & NSF \\
\hline 18.40 & 32.03 & 10.20 & 4.21 & 12.03 & 1.63 & 3.37 & 2.13 \\
$12.09^{* *}$ & $8.31 * *$ & $19.34 * *$ & $0.65^{*}$ & $4.02^{* *}$ & $1.62^{*}$ & $0.78^{* *}$ & $6284.9 * *$ \\
0.52 & 0.01 & 0.81 & 0.34 & 0.70 & 0.91 & 0.26 & 0.96 \\
\hline
\end{tabular}


Table 2 continued...

\begin{tabular}{c|c|c|c|c|c|c}
\hline DM & TSS & $\beta$ - CAR & TS & RS & NRS & YP \\
\hline 0.57 & 3.003 & 0 & 2.37 & 0.36 & 0.04 & 0 \\
$18.96^{* *}$ & $2.003^{* *}$ & $0.03^{* *}$ & $0.40^{*}$ & $0.61^{*}$ & $0.80^{* *}$ & $16.63^{* *}$ \\
0.09 & 0.98 & 0.001 & 0.20 & 0.25 & 0.03 & 1.03 \\
\hline
\end{tabular}

$*$ and $* *$ indicated significant at $5 \%$ and $1 \%$ level of probability, respectively

$\mathrm{DFMF}=$ Days to first male flower, DFFF $=$ Days to first female flower, NMFP $=$ Number of male flowers per plant, NFFP $=$ Number of female flowers per plant, NPBP $=$ Number of primary branches per plant, NSBP $=$ Number of secondary branches per plant, FD $=$ Fruit Diameter $(\mathrm{cm})$, FL $=$ Fruit length $(\mathrm{cm})$, FT $=$ Flesh thickness $(\mathrm{cm}), \mathrm{HW}=$ Hollowness $(\mathrm{cm})$, NFP $=$ Number of fruits per plant, SFW = Single fruit weight $(\mathrm{kg}), \mathrm{NSF}=$ Number of seeds per fruit, DM $(\%)=$ Dry matter content, TSS $(\%)=$ Total soluble solid, $\beta$ - CAR = Beta-carotene $(\mathrm{mg} / 100 \mathrm{~g})$, TS $=$ Total sugar $(\mathrm{g} / 100 \mathrm{~g}), \mathrm{RS}=$ Reducing sugar $(\mathrm{g} / 100 \mathrm{~g}), \mathrm{NRS}=$ Non-reducing sugar $(\mathrm{g} / 100 \mathrm{~g}), \mathrm{YP}=$ Yield per plant $(\mathrm{kg})$.

Genotypic, phenotypic and error variance, heritability (\%), genotypic and phenotypic coefficient of variation, genetic advance (GA), genetic advance in percent of mean have been presented in (Table $3 \& 4$ ) to show the extent of variation among the thirty genotypes. The magnitude of genotypic variance for days to first male flower, days to first female flower, number of male flowers per plant, number of female flowers per plant, fruit length, flesh thickness, hollowness, number of seeds per fruit, dry matter content, total soluble solid, beta-carotene, total sugar, reducing sugar, non-reducing sugar, yield per plant were higher than environmental variance and the genotypic and phenotypic variance were observed more or less similar. This indicates that the genotypic component of variation was the major contributor to the total variation. The environmental variance of the above traits were observed to be very low indicating that the environment had very little effect on observed phenotypic variation of the traits. These would also suggest that the above traits have broad variation and improvement can be achieved through the imposition of selection on the traits. Same result was reported by Aruah et al. (2012). On the other hand, environmental variance was higher than genotypic variance for number of primary branches, number of secondary branches, number of fruits per plant; single fruit weight and fruit diameter indicating that these characters were influenced more by environmental effect and selection based on these traits would not be effective reported by Islam et al. (2009).

The phenotypic coefficient of variation (PCV) was the highest in beta-carotene $(62.16 \%)$, number of secondary branches per plant $(52.57 \%)$, non-reducing sugar (43.54\%), flesh thickness $(41.86 \%)$, number of seeds per fruit $(34.10 \%)$, yield per plant $(33.08 \%)$, reducing sugar $(30.43 \%)$, number of fruits per plant $(26.91 \%)$ and single fruit weight $(26.08 \%)$. Khan et al. (2009) reported that high PCV is an indication of the existence of wide scope of selection for the improvement of the traits from a considerable amount of variability present. Comparatively low PCV observed for days to first female flower $(3.52 \%)$, days to first male flower $(6.77 \%)$, total soluble solid $(11.96 \%)$, total sugar $(15.65 \%)$, number of male flowers per plant $(17.25 \%)$, hollowness $(18.52 \%)$ and number of primary branches per plant (19.49\%) indicating less scope for selection. The highest genotypic coefficient of variation (GCV) was found for betacarotene $(61.88 \%)$ followed by non-reducing sugar $(40.28 \%)$, number of seeds per fruits (34.09\%), flesh thickness (33.58\%), yield per plant (30.22\%), number of female flower per plant $(24.97 \%)$, dry matter $(21.23 \%)$ and number of secondary branches per plant (20.24\%). Yadav (2000) reported that high GCV is the indication of exploitable genetic variability for these traits which may facilitate selection. 
A narrow range of difference between PCV and GCV was observed for days to first male flower (6.77 and 6.62) followed by days to first female flower (3.52 and 3.14), number of male flowers per plant (17.25 and 17.25), number of male flowers per plant (26.91 and 24.97), number of seeds per fruit (34.10 and 34.09), fruit length (20.30 and 19.09), dry matter (21.40 and 21.23) and beta-carotene (62.16 and 61.88). This indicates that the traits are mostly governed by genetic factors with minimal environmental influence on the phenotypic expression of the traits and selection of these traits on the basis of their phenotypic values may be effective as reported by Aruah et al. (2012). However, wide range of variation between PCV and GCV was reported for number of primary branches per plant (10.49 and 12.52), number of secondary branches (52.57 and 20.24), number of fruits per plant (32.42 and 14.66), single fruit weight (26.08 and 16.39), flesh thickness (41.86 and 33.58), hollowness (18.52 and 11.70), total soluble solid (11.96 and 6.11) and total sugar (15.65 and 7.76) indicating vulnerability of theses traits to environmental influence and thereby reducing the response to selection on phenotypic basis reported by Islam et al. (2009).

High heritability associated with high genetic advance in percent of mean was reported for number of male flower per plant (99.99 and 35.54), number of female flowers per plant (89.12 and 47.75), number of seeds per fruit (99.95 and 70.21), fruit length (88.38 and 36.97), yield per plant (83.41 and 56.85), flesh thickness (64.37 and 55.51), dry matter (98.43 and 43.38), beta-carotene (99.11 and 126.51) and non-reducing sugar ( 88.80 and 79.48). High heritability estimates associates with fairly high estimates of Genetic Advance in percent of mean (GAPM) demonstrate the presence of additive genes effect and selection for genetic improvement for this trait would be effective. Such high GA may be due to the action of additive genes reported by Idahosa et al. (2010).

Table 3. Estimation of genetic parameters for different traits in 30 pumpkin genotypes

\begin{tabular}{l|c|c|c|c|c|c|c}
\hline Parameter & DFMF & DFFF & NMFP & NFFP & NPBP & NSBP & NFP \\
\hline$\delta^{2} \mathrm{~g}$ & 28.43 & 7.24 & 152.22 & 5.16 & 0.58 & 2.10 & 0.23 \\
$\delta^{2} \mathrm{p}$ & 29.75 & 9.09 & 152.23 & 5.99 & 1.42 & 14.19 & 1.15 \\
$\delta^{2} \mathrm{e}$ & 1.32 & 1.85 & 0.005 & 0.83 & 0.83 & 12.09 & 0.91 \\
GCV & 6.62 & 3.14 & 17.25 & 24.97 & 12.53 & 20.24 & 14.66 \\
PCV & 6.77 & 3.52 & 17.25 & 26.91 & 19.49 & 52.57 & 32.42 \\
$\mathrm{~h}^{2} \mathrm{~b}(\%)$ & 95.55 & 79.65 & 99.99 & 89.12 & 41.35 & 14.81 & 20.44 \\
GA & 10.73 & 4.94 & 25.41 & 4.34 & 1.01 & 1.15 & 0.45 \\
GA $(\%)$ & 13.33 & 5.77 & 35.54 & 47.75 & 16.60 & 16.05 & 13.65 \\
\hline Range & $63-87.5$ & $80.75-90.5$ & $49.33-93$ & $4.33-13.33$ & $3.75-8.25$ & $3.5-11$ & $1.5-4.58$ \\
Mean & 80.50 & 85.66 & 71.49 & 9.09 & 6.11 & 7.16 & 3.30 \\
CV $(\%)$ & 1.43 & 1.59 & 0.10 & 10.03 & 14.93 & 10.15 & 28.92 \\
\hline
\end{tabular}

Table 3 Continued

\begin{tabular}{l|c|c|c|c|c|cc}
\hline Parameter & NSF & SFW $(\mathrm{kg})$ & FL $(\mathrm{cm})$ & FD $(\mathrm{cm})$ & YP $(\mathrm{kg})$ & FT $(\mathrm{cm})$ & HW $(\mathrm{cm})$ \\
\hline$\delta^{2} \mathrm{~g}$ & 2094.67 & 0.17 & 6.17 & 7.90 & 5.20 & 1.18 & 2.66 \\
$\delta^{2} \mathrm{p}$ & 2095.63 & 0.43 & 6.9 & 16.21 & 6.23 & 1.84 & 6.69 \\
$\delta^{2} \mathrm{e}$ & 0.96 & 0.26 & 0.81 & 8.31 & 1.03 & 0.65 & 4.02 \\
$\mathrm{GCV}$ & 34.09 & 16.39 & 19.09 & 14.64 & 30.22 & 33.58 & 11.70 \\
$\mathrm{PCV}$ & 34.10 & 26.08 & 20.30 & 20.97 & 33.08 & 41.86 & 18.52 \\
$\mathrm{~h}^{2} \mathrm{~b}(\%)$ & 99.95 & 39.49 & 88.38 & 48.75 & 83.41 & 64.37 & 39.87 \\
$\mathrm{GA}$ & 94.25 & 0.53 & 4.81 & 4.04 & 4.29 & 1.80 & 2.12 \\
$\mathrm{GA}(\%)$ & 70.21 & 21.22 & 36.97 & 21.06 & 56.85 & 55.51 & 15.22 \\
\hline Range & $43-258.2$ & $1.8-3.61$ & $9.3-18.4$ & $15.4-22.6$ & $3.2-12.66$ & $2.33-4.36$ & $10.9-16.1$ \\
Mean & 134.24 & 2.53 & 13.02 & 19.19 & 7.54 & 3.24 & 13.96 \\
CV $(\%)$ & 0.73 & 20.31 & 6.92 & 0.66 & 13.48 & 18.05 & 6.02 \\
\hline
\end{tabular}


Table 3 Continued...

\begin{tabular}{lcccccccc}
\hline Parameter & DM $(\%)$ & TSS $(\%)$ & $\beta$-CAR $(\mathrm{mg} / 100 \mathrm{~g})$ & TS $(\mathrm{g} / 100 \mathrm{~g})$ & RS $(\mathrm{g} / 100 \mathrm{~g})$ & $\mathrm{NRS}(\mathrm{g} / 100 \mathrm{~g})$ \\
\hline$\delta^{2} \mathrm{~g}$ & 6.28 & 0.34 & 0.011 & 0.06 & 0.11 & 0.25 \\
$\delta^{2} \mathrm{p}$ & 6.38 & 1.33 & 0.011 & 0.26 & 0.37 & 0.28 \\
$\delta^{2} \mathrm{e}$ & 0.09 & 0.98 & 0.001 & 0.20 & 0.25 & 0.03 \\
$\mathrm{GCV}$ & 21.23 & 6.11 & 61.88 & 7.76 & 17.17 & 40.98 \\
$\mathrm{PCV}$ & 21.40 & 11.96 & 62.16 & 15.65 & 30.43 & 43.54 \\
$\mathrm{~h}^{2} \mathrm{~b}(\%)$ & 98.43 & 26.10 & 99.11 & 24.62 & 31.85 & 88.60 \\
$\mathrm{GA}$ & 5.12 & 0.62 & 0.21 & 0.26 & 0.40 & 0.98 \\
$\mathrm{GA}(\%)$ & 43.38 & 6.43 & 126.51 & 7.94 & 19.97 & 79.48 \\
\hline Range & $6.83-17.9$ & $8.2-11$ & $0.02-0.54$ & $2.41-4.06$ & $1.2-2.77$ & $0.22-2.85$ \\
Mean & 11.81 & 9.66 & 0.17 & 3.31 & 2.01 & 1.23 \\
CV $(\%)$ & 2.70 & 10.28 & 0.03 & 13.60 & 25.12 & 14.69 \\
\hline
\end{tabular}

$\delta^{2} \mathrm{~g}=$ Genotypic variance, $\delta^{2} \mathrm{p}=$ Phenotypic variance, $\delta^{2} \mathrm{e}=$ Error variance, GCV $=$ Genotypic coefficient of variation, $\mathrm{PCV}=$ Phenotypic coefficient of variation, $\mathrm{h}^{2} \mathrm{~b}=$ Broad sense heritability, GA = Genetic advance, $\mathrm{GA}(\%)=$ Genetic advance in percent of mean.

DFMF $=$ Days to first male flower, DFFF $=$ Days to first female flower, NMFP $=$ Number of male flowers per plant, NFFP = Number of female flowers per plant, NPBP $=$ Number of primary branches per plant, $\mathrm{NSBP}=$ Number of secondary branches per plant, FD $=$ Fruit Diameter $(\mathrm{cm}), \mathrm{FL}=$ Fruit length $(\mathrm{cm}), \mathrm{NFP}=$ Number of fruits per plant, SFW $=$ Single fruit weight $(\mathrm{kg}), \mathrm{NSF}=$ Number of seeds per fruit, YP $=$ Yield per plant $(\mathrm{kg}), \mathrm{FT}=$ Flesh thickness $(\mathrm{cm}), \mathrm{HW}=$ Hollowness $(\mathrm{cm}), \mathrm{DM}(\%)=$ Dry matter content, TSS $(\%)$ $=$ Total soluble solid, $\beta$ - CAR = Beta-carotene $(\mathrm{mg} / 100 \mathrm{~g}), \mathrm{TS}=$ Total sugar $(\mathrm{g} / 100 \mathrm{~g}), \mathrm{RS}=$ Reducing sugar $(\mathrm{g} / 100 \mathrm{~g}), \mathrm{NRS}=$ Non-reducing sugar $(\mathrm{g} / 100 \mathrm{~g})$.

Number of female flowers had positive and significant correlation with number of fruits per plant and total sugar at genotypic level which indicated that number of fruits per plant and total sugar increased with the increase of number of female flowers. Number of primary branches showed positive and highly significant correlation with number of fruits per plant, single fruit weight, total sugar and yield per plant indicating that these characters can increase with the increase of number of primary branches. Number of fruits per plant and single fruit weight had positive and highly significant correlation with total sugar and yield per plant which showed that with the increase of number of fruits per plant and single fruit weight increase the amount of total sugar and yield per plant. But number of fruits per plant showed negative and significant correlation with reducing sugar which meant that the amount of reducing sugar decreased with the increase of number of fruits per plant.

Beta-carotene showed negative and significant correlation with reducing sugar at genotypic level and number of male flowers per plant both at genotypic and phenotypic level indicating that with the increase of number of male flowers decrease the amount of beta-carotene. Number of fruits per plant showed significant and positive correlation with yield per plant both at genotypic and phenotypic level. Number of male flowers per plant had positive correlation with single fruits weight indicating that increased number of male flowers per plant would also increase single fruit weight. Higher number of male flower indicating assurance of abundance of pollen causing large fruit size with more number of seeds per fruit (Aruah et al., 2012). The results of the path analysis revealed that number of fruits per plant $(0.370)$ had the maximum direct effect followed by days to first female flower (0.186) and number of male flowers per plant (0.1120). Maximum negative direct effect was observed for total sugar (-0.394) followed by number of female flowers per plant (-0.189) and reducing sugar (-0.096). 
Table 4. Genotypic $\left(\mathrm{r}_{\mathrm{g}}\right)$ and phenotypic $\left(\mathrm{r}_{\mathrm{p}}\right)$ correlation coefficient among twelve yield and quality related traits of pumpkin

\begin{tabular}{|c|c|c|c|c|c|c|c|c|c|c|c|c|}
\hline Characters & & DFFF & NMFP & NFFP & NPBP & NFP & SFW (kg) & TSS (\%) & $\begin{array}{l}\beta \text {-CAR } \\
(\mathrm{mg} / 100 \mathrm{~g}\end{array}$ & $\begin{array}{l}\mathrm{TS} \\
(\mathrm{g} / 100 \mathrm{~g})\end{array}$ & $\begin{array}{l}\mathrm{RS} \\
(\mathrm{g} / 100 \mathrm{~g})\end{array}$ & YP (kg) \\
\hline \multirow[t]{2}{*}{$\overline{\text { DFMF }}$} & $\mathrm{G}$ & 0.157 & -0.044 & 0.112 & -0.259 & -0.102 & -0.046 & -0.159 & 0.183 & -0.027 & -0.081 & -0.047 \\
\hline & $\mathrm{P}$ & 0.121 & -0.043 & 0.089 & -0.133 & -0.021 & -0.039 & -0.111 & 0.179 & -0.044 & -0.018 & -0.021 \\
\hline \multirow[t]{2}{*}{ DFFF } & $\mathrm{G}$ & & -0.043 & 0.060 & -0.120 & -0.185 & 0.252 & 0.045 & 0.264 & -0.352 & -0.076 & 0.196 \\
\hline & $\mathrm{P}$ & & -0.038 & 0.043 & -0.094 & -0.019 & 0.243 & 0.091 & 0.235 & -0.303 & -0.106 & 0.163 \\
\hline \multirow[t]{2}{*}{ NMFP } & $\mathrm{G}$ & & & -0.080 & 0.185 & 0.087 & 0.077 & -0.379 & $-0.411 * *$ & -0.101 & 0.360 & 0.137 \\
\hline & $\mathrm{P}$ & & & -0.074 & 0.119 & 0.039 & 0.048 & -0.193 & $-0.411^{*}$ & -0.049 & 0.203 & 0.125 \\
\hline \multirow[t]{2}{*}{ NFFP } & $\mathrm{G}$ & & & & -0.058 & 0.067 & -0.241 & 0.005 & 0.116 & $0.419 * *$ & -0.185 & -0.133 \\
\hline & $\mathrm{P}$ & & & & 0.012 & -0.095 & -0.084 & -0.077 & 0.108 & 0.232 & -0.156 & -0.144 \\
\hline \multirow[t]{2}{*}{ NPBP } & $\mathrm{G}$ & & & & & $0.649 * *$ & $0.470^{* *}$ & 0.137 & -0.289 & $0.705^{* *}$ & $0.675^{* *}$ & $0.410^{*}$ \\
\hline & $\mathrm{P}$ & & & & & 0.021 & 0.255 & 0.080 & -0.186 & 0.216 & 0.111 & 0.322 \\
\hline \multirow[t]{2}{*}{ NFP } & $\mathrm{G}$ & & & & & & 0.061 & -1.024 & 0.112 & $0.642 * *$ & $-0.631 * *$ & $0.989 * *$ \\
\hline & $\mathrm{P}$ & & & & & & -0.158 & -0.090 & 0.050 & 0.050 & 0.001 & $0.501 * *$ \\
\hline \multirow{2}{*}{ SFW (kg) } & $\mathrm{G}$ & & & & & & & -0.047 & -0.049 & $0.414 * *$ & $0.681 * *$ & $0.577 * *$ \\
\hline & $\mathrm{P}$ & & & & & & & 0.056 & -0.030 & 0.126 & 0.139 & 0.320 \\
\hline \multirow[t]{2}{*}{ TSS (\%) } & $\mathrm{G}$ & & & & & & & & 0.357 & -0.196 & $0.706^{* *}$ & $-0.628^{* *}$ \\
\hline & $\mathrm{P}$ & & & & & & & & 0.182 & -0.107 & -0.004 & -0.338 \\
\hline \multirow{2}{*}{$\begin{array}{l}\beta \text {-CAR } \\
(\mathrm{mg} / 100 \mathrm{~g})\end{array}$} & $\mathrm{G}$ & & & & & & & & & -0.155 & $-0.435^{* *}$ & 0.025 \\
\hline & $\mathrm{P}$ & & & & & & & & & -0.076 & -0.245 & 0.023 \\
\hline \multirow[t]{2}{*}{ TS $(g / 100 g)$} & $\mathrm{G}$ & & & & & & & & & & 0.061 & 0.228 \\
\hline & $\mathrm{P}$ & & & & & & & & & & 0.019 & 0.077 \\
\hline \multirow[t]{2}{*}{ RS (g/100g) } & $\mathrm{G}$ & & & & & & & & & & & -0.032 \\
\hline & $\mathrm{P}$ & & & & & & & & & & & 0.049 \\
\hline
\end{tabular}

Here, ** and $*$ indicates significant at $1 \%$ and $5 \%$ level of significance, respectively, $\mathrm{G}=$ Genotypic correlation, $\mathrm{P}=\mathrm{Phenotypic}$ correlation DFMF $=$ Days to first male flower, DFFF $=$ Days to first female flower, NMFP $=$ Number of male flowers per plant, NFFP $=$ Number of female flowers per plant, NPBP $=$ Number of primary branches per plant, NFP $=$ Number of fruits per plant, SFW $=$ Single fruit weight $(\mathrm{kg})$, TSS $(\%)=$ Total soluble solid, $\beta$ - CAR = Beta-carotene $(\mathrm{mg} / 100 \mathrm{~g})$, TS = Total sugar $(\mathrm{g} / 100 \mathrm{~g}), \mathrm{RS}=$ Reducing sugar $(\mathrm{g} / 100 \mathrm{~g})$, YP = Yield per plant $(\mathrm{kg})$. 
Table 5. Partitioning of genotypic correlation with fruit yield into direct (bold) and indirect components

\begin{tabular}{|c|c|c|c|c|c|c|c|c|c|c|c|c|}
\hline \multirow[b]{2}{*}{ Characters } & \multicolumn{11}{|c|}{ Indirect effect via } & \multirow{2}{*}{$\begin{array}{l}\text { Genotypic correlation } \\
\text { with yield }\end{array}$} \\
\hline & DFMF & DFFF & NMFP & NFFP & NPBP & NFP & SFW & TSS & $\beta$-CAR & TS & $\mathrm{RS}$ & \\
\hline DFMF & 0.035 & -0.008 & 0.006 & 0.022 & 0.002 & 0.093 & 0.007 & -0.006 & -0.007 & 0.030 & -0.019 & -0.047 \\
\hline DFFF & -0.001 & 0.186 & -0.009 & -0.035 & -0.001 & 0.028 & -0.065 & 0.010 & -0.002 & -0.142 & -0.013 & 0.196 \\
\hline NMFP & 0.002 & -0.014 & 0.112 & 0.011 & -0.0007 & -0.089 & 0.0009 & -0.002 & 0.008 & 0.073 & 0.012 & 0.137 \\
\hline NFFP & -0.004 & 0.034 & -0.006 & -0.189 & -0.007 & 0.174 & 0.023 & 0.007 & 0.014 & -0.266 & -0.039 & -0.133 \\
\hline NPBP & -0.006 & 0.016 & 0.007 & -0.123 & -0.011 & 0.022 & -0.171 & -0.002 & 0.013 & 0.249 & -0.095 & $0.410^{*}$ \\
\hline NFP & 0.008 & 0.014 & -0.027 & -0.089 & -0.0007 & 0.370 & -0.008 & 0.001 & 0.008 & -0.268 & -0.055 & $0.989 * *$ \\
\hline SFW & 0.001 & -0.070 & 0.0006 & -0.026 & 0.012 & -0.017 & 0.172 & -0.009 & -0.004 & -0.278 & 0.060 & $0.577 * *$ \\
\hline TSS & 0.009 & -0.076 & 0.013 & 0.054 & -0.001 & -0.018 & 0.061 & -0.025 & -0.003 & 0.171 & -0.002 & $-0.628 * *$ \\
\hline$\beta$-CAR & -0.012 & -0.018 & 0.047 & -0.133 & -0.007 & 0.153 & -0.033 & 0.003 & 0.021 & -0.024 & -0.022 & 0.025 \\
\hline TS & -0.002 & 0.067 & -0.020 & -0.128 & 0.007 & 0.252 & 0.121 & 0.011 & 0.001 & -0.394 & 0.003 & 0.228 \\
\hline $\mathrm{RS}$ & 0.006 & 0.025 & -0.014 & -0.077 & -0.013 & 0.213 & -0.108 & -0.0006 & 0.004 & 0.012 & -0.096 & -0.032 \\
\hline
\end{tabular}

Here, $* *$ and $*$ indicates significant at $1 \%$ and $5 \%$ level of significance, respectively, DFMF $=$ Days to first male flower, DFFF $=$ Days to first female flower, NMFP = Number of male flowers per plant, NFFP = Number of female flowers per plant, NPBP = Number of primary branches per plant, NFP $=$ Number of fruits per plant, SFW $=$ Single fruit weight $(\mathrm{kg})$, TSS $(\%)=$ Total soluble solid, $\beta-$ CAR $=$ Beta-carotene $(\mathrm{mg} / 100 \mathrm{~g}), \mathrm{TS}=\mathrm{Total}$ sugar $(\mathrm{g} / 100 \mathrm{~g}), \mathrm{RS}=$ Reducing sugar $(\mathrm{g} / 100 \mathrm{~g})$, YP = Yield per plant $(\mathrm{kg})$. 
Total soluble solid had negative direct effect as well as negative and highly significant genotypic correlation with yield (-0.628). The contributions of yield components like number of fruits per plant and single fruit weight $(\mathrm{kg})$ were higher in the present study. Husna et al. (2011) also found similar findings in bottle gourd. Positive direct effect was exhibited by yield per plant in building up the correlation with yield. Number of primary branches per plant, number of fruits per plant and single fruit had positive and highly significant genotypic correlation with yield. Days to first female flower, number of male flowers per plant, beta-carotene and total sugar had positive and insignificant genotypic correlation with yield. The contributions of negative and positive indirect effects via different parameters were responsible for exhibiting the negative total genotypic correlation with yield. The result of the present experiment revealed that a wide variation existed among the pumpkin genotypes. Also there was correlation of different yield components with the yield of pumpkin.

\section{REFERENCES}

Aruah C. B., M. I. Uguru and B. C. Oyiga. 2012. Genetic variability and inter-relationship among some Nigerian pumpkin accessions. International J. Pl. Breed. 6(1): 34-41.

BBS (Bangladesh Bureau of Statistics). 2009. Year Book of Agricultural Statistics in Bangladesh. Ministry of planning, Government of Peoples Republic of Bangladesh, Dhaka.

Bose, T. K. and M. G. Som. 1998 .Vegetable crops in India. Naya Prokash, Calcutta, India. pp. 92-95.

Brammer, H. 1971. Soil Resources, Soil Survey Project, Bangladesh. AGL: SF/ Pck.6. technical report 3. p.8.

Burton, G. W. 1952. Quantitative inheritance in grass Proc. 6 Grassl. Cong. 1: 277-283.

Dewey, D.K. and K. H. Lu. 1959. A correlation and path co-efficient analysis of components of crested wheat grass and production. Agron. J. 51: 515-518.

Husna, A., F. Mahmud, M.R. Islam, M.A.A. Mahmud and M. Ratna. 2011. Genetic variability, correlation and path co-efficient analysis in bottle gourd (Lagenariasiceraria L.). Advan. Biol. Res. 5 (6): 323-327.

Johnson, H. W., H. F. Robinson and R.E. Comstoc. 1955. Estimates of genetic and environmental variability in soybean. Agron. J. 47: 314-318.

Khan A. S. M. M. R., M. Y. Kabir and M. M. Alam. 2009. Variability, correlation, path analysis of yield and yield components of pointed gourd. J. Agric. Rural Development. 7: 93-98.

Lush, J. L. 1949. The characters studied in the path analysis. Press, Ames, Iowa. pp: 437.

Islam M. R., M. S. Hossain, M. S. R. Bhuiyan, A. Husna and M. A. Syed. 2009. Genetic Variability and Path-Coefficient Analysis of Bitter Gourd (Momordica charantia L.). International J. of Sustainable Agriculture 1 (3): 53-57.

Idahosa D. O., J. E. Alika, A. U. Omoregie. 2010. Genetic Variability, Heritability and Expected Genetic Advance as Indices for Yield and Yield Components Selection in Cowpea (Vigna unguiculata L.) Walp http://www.sciencepub.net/academia 2010:2(5).

Jahan, T. A., A. K. M. A. Islam, M. G. Rasul, M. A. K. Mian and M. M. Haque. 2012. Heterosis of Qualitative and Quantitative Characters in Sweet Gourd (Cucurbita moschata Duch.ex Poir). African Journal of Food, Agriculture, Nutrition and Development. 12(3): 6187-6200.

Rashid M. M. 2002. Nutrient component of Pumpkin. Shobji Biggan. Second Edition. Bangla Academy, Dhaka, Bangladesh. 66-69.

Tindall, H. D. 1987. Vegetables in the Tropics. Macmillan Education, London. P.166.

Yadav, R. K. 2000. Studies on genetic variability for some quantitative characters in rice (Oryza sativa L.). Advances in Agric. Res. 13: 205-207.

Yawalkar K. S. 1991. Vegetable crop in India. Agri-Horticultural Publishing House, Nagpur. 182186. 